\title{
The impact of cosmetic breast implants on breastfeeding: a systematic review and meta-analysis
}

\author{
Michal Schiff ${ }^{1}$, Charles S Algert ${ }^{1}$, Amanda Ampt ${ }^{1}$, Mark S Sywak ${ }^{2,3}$ and Christine L Roberts ${ }^{1{ }^{*}}$
}

\begin{abstract}
Background: Cosmetic breast augmentation (breast implants) is one of the most common plastic surgery procedures worldwide and uptake in high income countries has increased in the last two decades. Women need information about all associated outcomes in order to make an informed decision regarding whether to undergo cosmetic breast surgery. We conducted a systematic review to assess breastfeeding outcomes among women with breast implants compared to women without.

Methods: A systematic literature search of Medline, Pubmed, CINAHL and Embase databases was conducted using the earliest inclusive dates through December 2013. Eligible studies included comparative studies that reported breastfeeding outcomes (any breastfeeding, and among women who breastfed, exclusive breastfeeding) for women with and without breast implants. Pairs of reviewers extracted descriptive data, study quality, and outcomes. Rate ratios (RR) and 95\% confidence intervals (Cl) were pooled across studies using the random-effects model. The Newcastle-Ottawa scale (NOS) was used to critically appraise study quality, and the National Health and Medical Research Council Level of Evidence Scale to rank the level of the evidence. This systematic review has been registered with the international prospective register of systematic reviews (PROSPERO): CRD42014009074.
\end{abstract}

Results: Three small, observational studies met the inclusion criteria. The quality of the studies was fair (NOS 4-6) and the level of evidence was low (III-2 - III-3). There was no significant difference in attempted breastfeeding (one study, RR 0.94, 95\% Cl 0.76, 1.17). However, among women who breastfed, all three studies reported a reduced likelihood of exclusive breastfeeding amongst women with breast implants with a pooled rate ratio of 0.60 (95\% Cl 0.40, 0.90).

Conclusions: This systematic review and meta-analysis suggests that women with breast implants who breastfeed were less likely to exclusively feed their infants with breast milk compared to women without breast implants.

Keywords: Breastfeeding, Breast implants, Mammoplasty, Systematic reviews, Meta-analysis

\section{Background}

Since the introduction of silicone gel and saline breast implants for cosmetic enhancement of breast size in the early 1960 's, breast augmentation has become one of the most common plastic surgery procedures worldwide [1]. In 2012, 286,000 women in the U.S. had breast augmentation surgery - an increase of $877 \%$ from 1992, when the American Society of Plastic Surgeons began formulating

\footnotetext{
* Correspondence: clroberts@med.usyd.edu.au

${ }^{1}$ Clinical and Population Perinatal Health Research, Kolling Institute, University of Sydney, Sydney, New South Wales, Australia

Full list of author information is available at the end of the article
}

yearly national cosmetic surgical statistics [2]. The majority of women who undergo such surgery do so during their reproductive years [3], despite ambiguity regarding the risks to breastfeeding success associated with breast implants.

Breastfeeding has immediate and longer term nutritional, gastrointestinal, immunological, and neurodevelopmental benefits to the baby, and psychosocial benefits for the mother [4]. World Health Organization recognises that while providing some breast milk to the infant is better than none, exclusive breastfeeding is needed to achieve optimal growth, development, and health for 
infants [5]. If supplementary formula feeding is initiated, the infant does not receive the full advantages of exclusive breastfeeding and the breastfeeding mother must also engage in a complicated balancing act between maintaining or increasing the existing supply while ensuring the infant receives adequate nourishment. The potential to compromise lactation as a result of breast augmentation is particularly relevant with regards to cosmetic breast surgery, which is an elective procedure motivated by aesthetic appeal, rather than in reconstructive surgery (such as following mastectomy). Since there is an element of choice, women need information about all associated risks, both short and long term, in order to make an informed decision regarding whether to undergo cosmetic breast surgery.

The internet currently serves as a prominent source of medical information for people considering plastic surgery $[6,7]$. However, a considerable amount of the information accessed through search engines regarding breast augmentation in general and its effects on lactation in particular is either misleading or inaccurate $[8,9]$. Other media have also been shown to be unbalanced, with two thirds of the feature articles on cosmetic surgery in the UK portraying it as risk-free with no mention of potential problems or complications [10]. With the abundance of very accessible, unfiltered sources of information, there is a need for evidence based evaluation of the risk to future breastfeeding ability that can be offered to women considering breast augmentation. The aim of this systematic review is to assess breastfeeding outcomes among women with bilateral cosmetic breast augmentation (also referred to as breast implants, mammoplasty and mammaplasty) compared to women without breast surgery [11]. Specifically to assess 1 ) the rate of any breastfeeding and 2) among women who breastfeed, the rate of exclusive breastfeeding.

\section{Methods}

\section{Search methods}

A systematic search of published studies in Medline, PubMed, CINAHL and Embase databases using earliest inclusive dates through December 2013 was employed. The search strategy combined terms related to breast surgery along with terms related to breastfeeding, using both subject headings and key words when applicable. There were no language or any other restrictions. The specific search strings used for each of the databases is given in Table 1. The database search was supplemented by handsearching reference lists of relevant publications.

Table 1 Specific search strings used for each of the databases

\begin{tabular}{|c|c|c|c|c|}
\hline $\begin{array}{l}\text { String } \\
\text { number }\end{array}$ & Medline & Embase & PubMed & CINAHL \\
\hline 1 & exp breast implant/ & Breast Implants/ & Breast-surgery & Breast implants \\
\hline 2 & breast augmentation/ & Breast Implantation/ & Breast-implants & Breast augmentation \\
\hline 3 & exp breast reconstruction/ & exp Mammaplasty/ & Breast-implantation & Augmentation mammaplasty \\
\hline 4 & exp breast prosthesis/ & exp "Prostheses and Implants"/ & Breast-prosthesis & Augmentation mammoplasty \\
\hline 5 & exp breast surgery/ & Breast/su [Surgery] & Mammaplasty & Breast enlargement \\
\hline 6 & exp plastic surgery/ & Surgery, Plastic/ & Mammoplasty & Silicones \\
\hline 7 & mammaplasty.mp. & mammaplasty.mp. & Breast-augmentation & Breast reconstruction \\
\hline 8 & mammoplasty.mp. & mammoplasty.mp. & Breast-enlargement & Breast surgery \\
\hline 9 & breast augmentation.mp. & breast augmentation.mp. & Breast and plastic-surgery & Plastic surgery \\
\hline 10 & breast enlargement.mp. & breast enlargement.mp. & $\begin{array}{l}1 \text { or } 2 \text { or } 3 \text { or } 4 \text { or } 5 \text { or } 6 \text { or } 7 \\
\text { or } 8 \text { or } 9\end{array}$ & $\begin{array}{l}1 \text { or } 2 \text { or } 3 \text { or } 4 \text { or } 5 \text { or } 6 \text { or } 7 \\
\text { or } 8 \text { or } 9\end{array}$ \\
\hline 11 & breast surgery.mp. & breast surgery.mp. & Breastfeeding & Breastfeeding \\
\hline 12 & $\begin{array}{l}1 \text { or } 2 \text { or } 3 \text { or } 4 \text { or } 5 \text { or } 6 \text { or } 7 \text { or } 8 \text { or } \\
9 \text { or } 10 \text { or } 11\end{array}$ & $\begin{array}{l}1 \text { or } 2 \text { or } 3 \text { or } 4 \text { or } 5 \text { or } 6 \text { or } 7 \text { or } \\
8 \text { or } 9 \text { or } 10 \text { or } 11\end{array}$ & Breast feeding & Breast feeding \\
\hline 13 & exp breast feeding/ & exp Breast Feeding/ & Lactation & Lactation \\
\hline 14 & exp lactation/ & exp Lactation/ & & 11 or 12 or 13 \\
\hline 15 & breast milk/ & breastfeeding.mp. & 11 or 12 or 13 & 10 and 14 \\
\hline 16 & breastfeeding.mp. & breast feeding.mp. & 10 and 15 & \\
\hline 17 & breast feeding.mp. & lactation.mp. & & \\
\hline 18 & lactation.mp. & 13 or 14 or 15 or 16 or 17 & & \\
\hline 19 & 13 or 14 or 15 or 16 or 17 or 18 & 12 and 18 & & \\
\hline 20 & 12 and 19 & & & \\
\hline
\end{tabular}




\section{Eligibility criteria and outcomes}

Studies comparing women who have undergone breast augmentation to women without prior breast augmentation were eligible for inclusion [11]. The outcomes of interest were 1) breastfeeding rates and, 2) among the women who breastfeed, exclusive breastfeeding at the time of assessment. Exclusive breastfeeding was defined as providing only breast milk (directly from the breast or as expressed breast milk) or as defined by the study. Non-exclusive breast milk feeding included any use of breast milk substitute/formula feeding or insufficient lactation as defined by the study.

\section{Study selection}

The review allowed the inclusion of clinical trials and observational studies (cohort, case-control, or crosssectional studies), but excluded case series or reports, guidelines, comments or reviews without original data [11]. We also excluded studies of women with breast augmentation subsequent to treatment for breast cancer, studies with a comparison group that comprised women with other types of breast surgery, and those lacking a control group altogether.

\section{Data extraction}

The titles and abstracts of all articles identified from the systematic search were screened. The full-text of potentially eligible articles was reviewed for inclusion by at least two independent assessors. Any disagreements regarding inclusion of particular studies were resolved through discussion. After the final list of studies to be included was established, data on the primary and secondary outcomes were extracted independently by two reviewers using a standard form. Results were compared and any discrepancies were resolved through discussion and/or following consultation with a third reviewer.

\section{Quality assessment}

To assess the risk of bias within the included studies, the Newcastle-Ottawa Scale (NOS) for assessing the quality of non-randomized studies in meta-analyses was utilised [12]. Using this scale, a non-randomized study can be awarded a maximum of nine stars on items related to the selection of the study groups (four stars), the comparability of the exposed and unexposed groups (two stars), and the ascertainment of outcomes of interest (three stars). Prior to the rating process, we tailored the scale to capture potential sources of bias relevant to the included studies by pre-specifying the desired minimum duration of follow up to one month postpartum, as well as identifying the main confounding factors (maternal age, parity, intention to breastfeed, gestation at birth and mode of delivery). As the NOS compares nonrandomized studies within study design groups, the strength of the evidence was also ranked on the National Health and Medical Research Council Level of Evidence Scale [13]. Using this scale studies are ranked as Level I Evidence for systematic reviews of randomized controlled trials, II for randomized controlled trials, III-1 for pseudorandomized trials, III-2 for comparative studies with concurrent controls, III-3 for comparative studies without concurrent controls and IV for case series. The included studies were rated independently by three reviewers, the scores and ranks were compared, and any differences in scoring were resolved through discussion.

\section{Statistical analysis}

The rate of any breastfeeding following a birth subsequent to breast augmentation, and the rate of exclusive breastfeeding was calculated from the raw data presented in the included papers. The outcomes were assessed for all women in the studies and in a post-hoc subgroup analysis by incision type. For outcomes from two or more contributing studies, rate ratios (RR) from each study were pooled using a random effects metaanalysis, with trials weighted by their inverse variance [14]. Stata's "metan" command was used to perform the meta-analyses. The degree of variability across studies was summarized using the $\mathrm{I}^{2}$ statistic that estimates the percentage of total variation across the studies that is due to heterogeneity rather than chance [15].

\section{Results}

Systematic database searches yielded 1435 records, of which 936 were unique citations. A further 10 papers were identified through hand searching. Of 946 unique records, 941 were excluded based on the title and/or abstract as they were irrelevant to the review, did not include the exposure or outcomes of interest, or failed to meet the other stated criteria (Figure 1). Only five fulltext articles were reviewed, of which two were excluded due to inability to distinguish pregnancies before and after breast augmentation [16], or between breast augmentation and other breast surgeries [17].

The characteristics of the three included studies are summarised in Table 2. All included studies were hospitalbased cohort studies (Evidence Levels III-2 - III-3), enrolling women from either a surgery clinic, a maternity ward, or a lactation support service. Andrade et al. [18] excluded women with more than one type of plastic surgery of the breast, thus not including women with augmentation subsequent to mastectomy, whereas Cruz and Korchin [19] and Hurst [20]'s studies lack any reference to whether women with breast implants for reconstructive purposes were included. While Cruz and Korchin [19] included only women with saline implants in their study cohort, information on implant type is not indicated in the two other studies. Both Cruz and Korchin [19] and Hurst [20], 


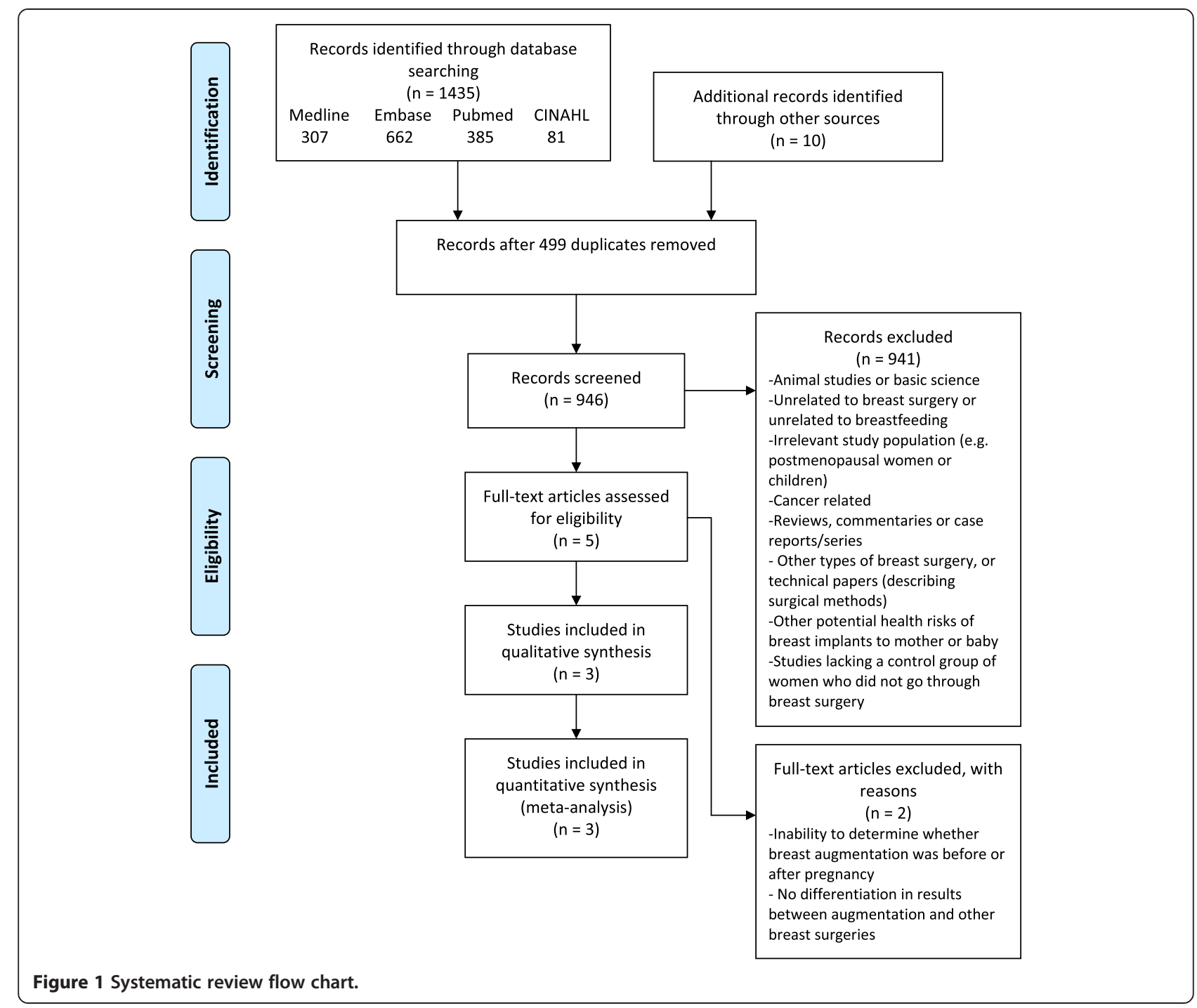

report their findings by the type of incision made for the breast implantation (sub/inframammary or periaerolar). Only one study [18] attempted to reduce confounding by restricting the cohort to 'healthy' infants, 'healthy' breasts, and mothers without a history of low breast milk production. In contrast, Hurst [20] primarily recruited mothers whose infants were both hospitalized in a children's hospital and referred to the hospital's lactation support team. Many of these were high risk babies with high rates of preterm birth and low birth weight. Cruz and Korchin [19] recruited women with small breasts who were evaluated for possible breast augmentation. For women who had previously had children, prior breastfeeding experience was obtained, although the number of children, duration since birth and intention to breastfeed were not reported. Breastfeeding outcomes were then compared to those of women who had a birth subsequent to breast augmentation [19].
The quality of the studies was fair (NOS scores 4-6) and the strength of evidence was low (Evidence Levels III-2 - III-3) (Table 2). NOS scores were reduced for deriving the study population from a single hospital or clinic [18-20], incomplete description of how the exposed cohort was identified [18], selection of cases and controls from different time periods that may lead to biases [19], limited attempt to control for potential confounders [19], using a matched design but an unmatched analysis [20], relying on self-report rather than observation for the assessment of breastfeeding [18-20], followup duration shorter than one month [19], and lacking information on loss to follow-up [20].

Assessed outcomes differed considerably across studies. While Cruz and Korchin [19] and Andrade et al. [18] chose to define a time point at which the success of breastfeeding was assessed (two weeks and one month, respectively), Hurst [20] evaluated the overall success of 
Table 2 Characteristics of the three included studies

\begin{tabular}{|c|c|c|c|c|c|c|c|c|}
\hline $\begin{array}{l}\text { Author, } \\
\text { year }\end{array}$ & Location & $\begin{array}{l}\text { Study } \\
\text { period }\end{array}$ & $\begin{array}{l}\text { Study } \\
\text { design }\end{array}$ & $\begin{array}{l}\text { Study } \\
\text { population }\end{array}$ & Cases & Controls & Data source & $\begin{array}{l}\text { Outcomes, NOS } \\
\text { Score and } \\
\text { LOE rank } \\
\end{array}$ \\
\hline \multirow[t]{3}{*}{$\begin{array}{l}\text { Hurst } \\
{[20]}\end{array}$} & \multirow[t]{3}{*}{$\begin{array}{l}\text { Texas, U.S.A. } \\
\text { Lactation } \\
\text { support } \\
\text { program in } \\
\text { a single } \\
\text { children's } \\
\text { hospital }\end{array}$} & \multirow[t]{3}{*}{ 1990-1995 } & \multirow[t]{3}{*}{$\begin{array}{l}\text { Retrospective } \\
\text { cohort study }\end{array}$} & \multirow[t]{3}{*}{$\begin{array}{l}5066 \text { mothers of } \\
\text { babies who were } \\
\text { admitted or } \\
\text { referred ( 15\% } \\
\text { from primary } \\
\text { care) to a tertiary } \\
\text { children's } \\
\text { hospital lactation } \\
\text { program }\end{array}$} & \multirow[t]{3}{*}{$\begin{array}{l}42 \text { women } \\
\text { with implants } \\
\text { who attempted } \\
\text { breastfeeding }\end{array}$} & \multirow[t]{3}{*}{$\begin{array}{l}42 \text { women } \\
\text { without implants } \\
\text { who attempted } \\
\text { breastfeeding } \\
\text { (matched on year, } \\
\text { lactation course, } \\
\text { age, parity and } \\
\text { breastfeeding } \\
\text { experience) }\end{array}$} & \multirow[t]{3}{*}{$\begin{array}{l}\text { Lactation follow-up } \\
\text { records, documenting } \\
\text { breastfeeding progress } \\
\text { weekly during infant's } \\
\text { hospitalization and } \\
\text { every other week after } \\
\text { discharge (by phone), } \\
\text { until 2-3 months } \\
\text { postpartum or until } \\
\text { breastfeeding ceased }\end{array}$} & $\begin{array}{l}\text { Exclusive breast } \\
\text { milk feeding or } \\
\text { insufficient } \\
\text { breastfeeding } \\
\text { (defined as little or } \\
\text { no lactogenesis or } \\
\text { low infant growth } \\
\text { with exclusive } \\
\text { breastfeeding) }\end{array}$ \\
\hline & & & & & & & & $\mathrm{NOS}=5$ \\
\hline & & & & & & & & $\mathrm{LOE}=\|\|-2$ \\
\hline \multirow[t]{3}{*}{$\begin{array}{l}\text { Andrade } \\
\text { [18] }\end{array}$} & \multirow[t]{3}{*}{$\begin{array}{l}\text { Brazil, single } \\
\text { maternity } \\
\text { hospital }\end{array}$} & \multirow[t]{3}{*}{$2004-2005$} & \multirow[t]{3}{*}{ Cohort study } & \multirow[t]{3}{*}{$\begin{array}{l}\text { Women giving } \\
\text { birth at the } \\
\text { hospital and } \\
\text { who attempted } \\
\text { breastfeeding }\end{array}$} & \multirow[t]{3}{*}{$\begin{array}{l}24 \text { women } \\
\text { with implants }\end{array}$} & \multirow[t]{3}{*}{$\begin{array}{l}25 \text { women } \\
\text { without implants, } \\
\text { selected from } \\
\text { same floor as } \\
\text { cases }\end{array}$} & \multirow[t]{3}{*}{ Assessment at home } & $\begin{array}{l}\text { Exclusive and } \\
\text { nonexclusive } \\
\text { breastfeeding at } \\
1 \text { month }\end{array}$ \\
\hline & & & & & & & & $\mathrm{NOS}=6$ \\
\hline & & & & & & & & $L O E=\| I \mid-2$ \\
\hline \multirow[t]{3}{*}{$\begin{array}{l}\text { Cruz and } \\
\text { Korchin } \\
{[19]}\end{array}$} & \multirow[t]{3}{*}{$\begin{array}{l}\text { Puerto Rico. } \\
\text { Presumably } \\
\text { a single } \\
\text { plastic } \\
\text { surgery } \\
\text { clinic }\end{array}$} & \multirow[t]{3}{*}{$\begin{array}{l}12 \text { month } \\
\text { period, } \\
\text { year not } \\
\text { reported }\end{array}$} & \multirow[t]{3}{*}{$\begin{array}{l}\text { Retrospective } \\
\text { cohort study }\end{array}$} & \multirow[t]{3}{*}{$\begin{array}{l}\text { 18-40 year old } \\
\text { women with } \\
\text { small breasts } \\
\text { who were } \\
\text { evaluated for } \\
\text { possible breast } \\
\text { augmentation }\end{array}$} & \multirow[t]{3}{*}{$\begin{array}{l}105 \text { women } \\
\text { with saline } \\
\text { implants who } \\
\text { subsequently } \\
\text { had children }\end{array}$} & \multirow[t]{3}{*}{$\begin{array}{l}107 \text { women who } \\
\text { had children prior } \\
\text { to evaluation for } \\
\text { implants }\end{array}$} & \multirow[t]{3}{*}{$\begin{array}{l}\text { Self-administered } \\
\text { questionnaire at } \\
\text { initial consultation } \\
\text { (controls) or at } \\
\text { regular follow-up } \\
\text { visit (cases) }\end{array}$} & $\begin{array}{l}\text { Attempted } \\
\text { breastfeeding; } \\
\text { successful } \\
\text { breastfeeding for } \\
\geq 2 \text { weeks, } \\
\text { including exclusive } \\
\text { and non-exclusive } \\
\text { breastfeeding }\end{array}$ \\
\hline & & & & & & & & $\mathrm{NOS}=4$ \\
\hline & & & & & & & & $\mathrm{LOE}=|\||-3$ \\
\hline
\end{tabular}

NOS Newcastle-Ottawa Scale assessing the quality of nonrandomized studies in meta-analyses [12].

LOE National Health and Medical Research Council Level of Evidence Scale [13].

lactogenesis and breastfeeding up to 2-3 months postpartum or until breastfeeding ceased. Notably, while Hurst [20] and Andrade et al. [18] explicitly defined breastfeeding as infants receiving breast milk, whether directly from the breast or as expressed milk, it is unclear whether Cruz and Korchin [19] included expressed breast milk when referring to "successful breastfeeding".

Of the three included studies, only Cruz and Korchin [19] included both women attempting to breastfeed or not, and found similar rates of attempted breastfeeding for women with $(59 \%)$ and without (63\%) breast augmentation (RR 0.94, 95\% CI 0.76, 1.17) including 37\% and 55\%, respectively, reporting any breastfeeding at 2 weeks (RR $0.67,95 \%$ CI $0.50,0.91)$. These rates did not differ by incision type. However, among women who breastfed, all three studies [18-20] reported a reduced likelihood of exclusive breastfeeding for women with breast augmentation with a pooled rate ratio of 0.60 (95\% CI 0.40, 0.90) (Figure 2). Alternatively, if the outcome is formulated as non-exclusive breastfeeding then the pooled analysis gives a 3-fold increase (RR 3.00, 95\% CI 1.16, 7.80) in the use of supplementary formula feeding among women with breast implants who attempt to breastfeed. Of the two studies that examined outcomes by incision type $[19,20]$, sub/ inframammary incisions were associated with a reduction in exclusive breastfeeding (pooled RR 0.61, 95\% CI 0.46, 0.82 ) compared to women with breast implants whereas periareolar incisions had a wide confidence interval (pooled RR 0.32, 95\% CI 0.04, 2.51) which did not provide evidence of an effect.

\section{Discussion}

Despite the frequency and increasing popularity of breast augmentation [21], this systematic review highlights a lack in the quality and strength of evidence to inform women considering cosmetic breast implants about the potential impact on successful breastfeeding. Although women with breast augmentation were found to be as likely to attempt breastfeeding as women without breast augmentation, women with breast augmentation were less likely to exclusively feed their infants with breast milk. However, the first finding is based on a single study and the second on only three, with none of the included studies having high quality or level of evidence scores $[12,13]$. Reduced likelihood of exclusive breastfeeding may be attributed directly or indirectly to: the augmentation surgery or the inserted 


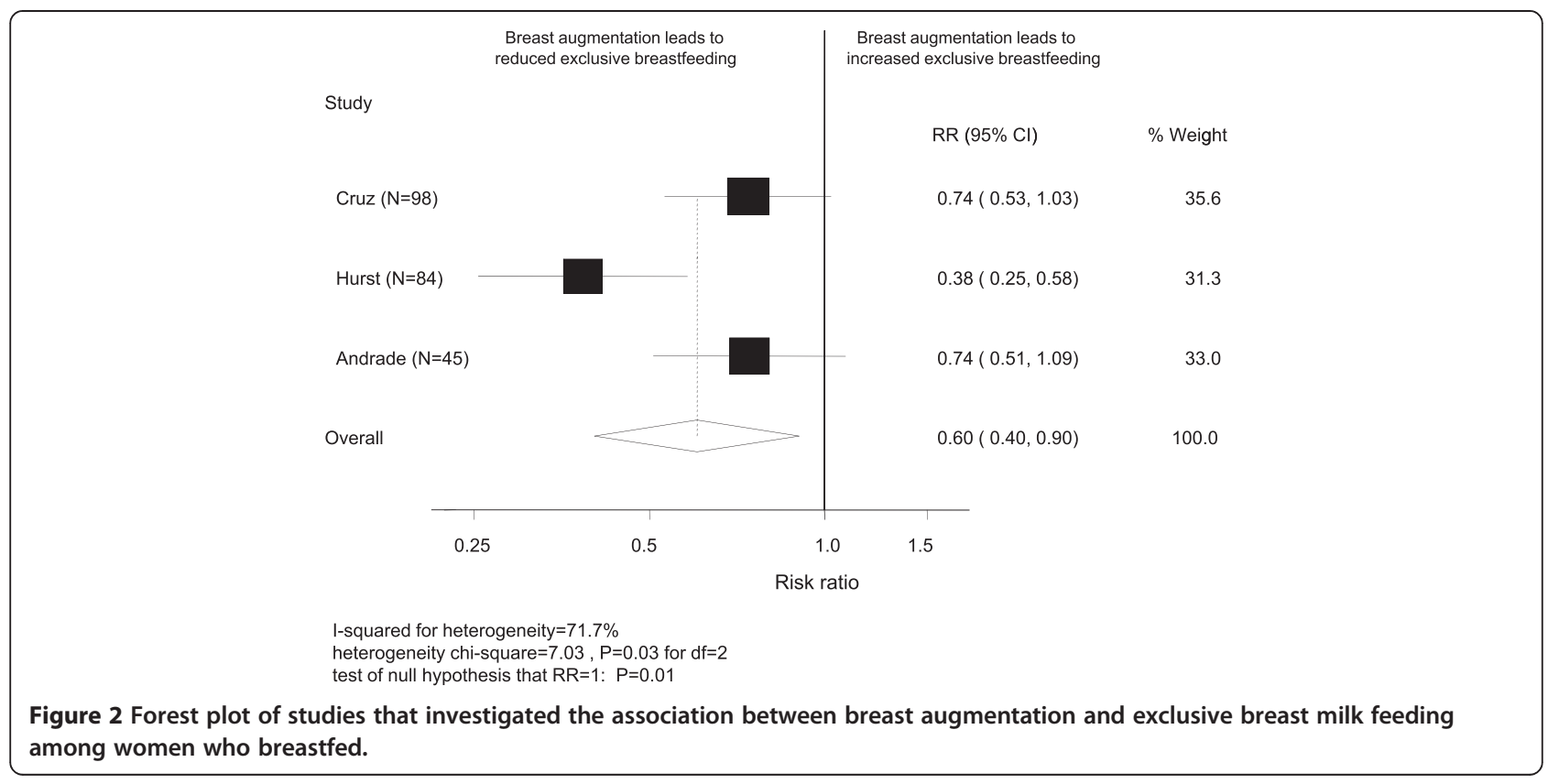

breast implants, an underlying condition (breast hypoplasia), or different attitudes and expectations among women who have breast augmentation surgery.

Breast implantation surgery can cause damage to ducts, glandular tissue, or innervation of the breast [22,23]. Alternatively, breast implants may place pressure on the breast tissue, which can damage the breast tissue or block lactiferous ducts [20]. Reduced capacity to lactate can also result from surgery-related complications [24,25], the most common of which are capsular contracture, hematoma formation, infection, or pain that can turn breastfeeding into a painful experience. The effect of such complications on breastfeeding has been documented in several case studies [26-29]. Risk to lactation capacity increases with time from the initial surgery as some women face the need to undergo reoperation to maintain or improve an initial result, or to treat complications [22]. The studies included in this review did not add to our knowledge of the specific mechanisms by which breast augmentation may disrupt normal breastfeeding function, as there was no detailed information on the surgical history and prevalence of complications was not reported.

Another possible explanation of our findings is the presurgical condition of breast hypoplasia, which may be especially prevalent among women choosing breast augmentation. Given current evidence, we are unable to rule out this condition as the cause of reduced milk production and the need to supplement breastfeeding with breast milk substitute. This condition of insufficient glandular tissue often characterised by small, asymmetrical, or unusually (mostly tubular) shaped breasts, a wide intramammary space and enlarged areolas - can significantly reduce milk production [30]. The incidence of hypoplastic breasts in the general population or its proportion among women choosing to go through breast implantation is unknown. In this regard, Cruz and Korchin's control cohort of women with previous births who subsequently presented as candidates for breast augmentation may have allowed them to control for pre-surgical conditions [19]. Thus, this study potentially points to the implantation surgery itself, rather than pre-surgical hypoplasia, as the cause of reduced exclusive breastfeeding rates. However, as Cruz and Korchin do not demonstrate the comparability of their cohorts at the time of giving birth (e.g. maternal age, parity, and socio-economic status) [19], differences in the women could also explain the findings.

The observed association of breast augmentation with supplementary feeding could also result from a difference in attitudes and beliefs towards breastfeeding. Women who chose breast augmentation may be more likely to give up breastfeeding once challenged with lactation difficulties, due to prior expectations and lower self-confidence in being able to meet infant's needs. Alternatively, they may show less perseverance when faced with obstacles due to having a reduced sense of commitment to breastfeed in the first place. Studies of the psychological status of women seeking cosmetic intervention have focused on body image dissatisfaction, low self-esteem and mental health conditions [31-34]. However, attitudes to breastfeeding and their role in preoperative decision making processes and postoperative patient satisfaction, have received little attention. The lack of studies may suggest that maintaining lactation ability is not even part of what most women are concerned with when considering breast 
augmentation [35]. This may result from the perception of breasts in western culture as sexual, rather than functional organs designed for the feeding of young [36], and is likely exacerbated by advertising that suggests formula and breast milk are equivalent sources for a baby's nutrition [37-39]. Clarifying the exact reasons for the observed effect requires further research, not only to explore physical causes of reduced breastfeeding capability associated with breast augmentation, but also to elucidate the contribution of psychosocial factors to this intricate picture.

It is problematic to infer no difference in the likelihood of women with breast augmentation attempting to breastfeed based on one small study with a relatively low rate of attempted breastfeeding (59-63\%) [19]. Furthermore as this study included only women with saline implants [19], it is possible that the findings do not apply to women with silicone implants. Between 1992 and 2006 the U.S. Food and Drug Administration (FDA) placed silicone gel-filled breast implants in moratorium as a result of serious safety concerns $[40,41]$. These included concern about the wellbeing of breastfed infants of mothers with silicone gel implants, which was addressed by extensive research aimed at examining the silicone contents of breast milk $[42,43]$ and its implications on infant oesophageal disorders [44-46]. Although no conclusive evidence was found, psychological studies during this period showed that the moratorium and its media coverage had a marked effect on preoperative concerns and postoperative levels of satisfaction of breast augmentation patients $[47,48]$. It is reasonable to speculate that women with silicone implants who gave birth during the years following the moratorium were less likely to attempt breastfeeding due to hesitance towards the safety of their breast milk [49].

Overall, our systematic search of the literature demonstrated how little has been studied regarding the impact of breast augmentation on breastfeeding outcomes. Surprisingly, although breast implants have a history of more than half a century, and in spite of constant development of new and improved augmentation techniques, only three studies were found to examine this important issue using adequate, no-surgery control groups. These three studies included small cohorts of women, drawn from only a single source, and were based on heterogeneous study populations (Level III evidence) [13]. Based on two studies, we found a reduction in exclusive breastfeeding in the subgroup of women with submammary incisions at augmentation surgery, but could not make a conclusion about those with periareolar incisions. It should be noted that the subgroup analyses were post-hoc and need to be interpreted with caution. Questions related to the implications of implant type (saline vs. silicone) and volume on maintaining breastfeeding capacity have hardly been explored. Further, the three included studies varied in the selected endpoints for assessment of breastfeeding, possibly influencing their ability to capture the difference in breastfeeding course between women with and without breast implants. The heterogeneity across the included studies, along with their moderate scores on the NOS risk of bias assessment, indicates that the effect of breast augmentation may vary depending on maternal characteristics and the need to interpret the pooled estimates with care.

\section{Conclusions}

Our systematic review suggests that breast augmentation is associated with $40 \%$ decrease in the likelihood of exclusive breastfeeding among women who breastfeed. However, our finding is based on only three relatively small and heterogeneous studies, and therefore is limited in its external validity. To explore the uncertainty about the observed association and clarify the many unknowns surrounding this issue, more research is required, using larger cohorts and more representative study populations. This information is vital to enable informed decision-making for more than an estimated million women worldwide going through breast implantation surgery each year.

\section{Competing interests}

The authors declare that they have no competing interests.

\section{Authors' contributions}

CLR and MSS conceived the study and CLR coordinated the project. All authors participated in the study design, planning of analysis and interpretation of the results. CSA undertook the statistical analyses and provided statistical expertise. MS and CLR drafted the manuscript, AA and MSS provided clinical expertise. All authors critically reviewed drafts of the manuscript, and read and approved the final manuscript.

\section{Acknowledgements}

We thank Melisa Litchfield for assistance with protocol development and data extraction. This work was supported by an Australian National Health and Medical Research Council (NHMRC) Centre for Research Excellence Grant (1001066). CLR is supported by a NHMRC Senior Research Fellowship (\#APP1021025) and AA is supported by the Dr Albert McKern Research Scholarship.

\section{Author details}

${ }^{1}$ Clinical and Population Perinatal Health Research, Kolling Institute, University of Sydney, Sydney, New South Wales, Australia. ${ }^{2}$ University of Sydney Endocrine Surgery Unit, Sydney, New South Wales, Australia. ${ }^{3}$ Department of Endocrine and Oncology Surgery, Royal North Shore Hospital, Sydney, New South Wales, Australia.

Received: 19 June 2014 Accepted: 5 October 2014 Published: 17 October 2014

\section{References}

1. International Society of Aesthetic Plastic Surgery: ISAPS International Survey on Aesthetic/Cosmetic Procedures Performed in 2011. http:// www.isaps.org/Media/Default/global-statistics/ISAPS-Results-Procedures2011.pdf (accessed October 2014)

2. American Society of Plastic Surgeons: 2012 Plastic Surgery Statistics Report. http://www.plasticsurgery.org/Documents/news-resources/ statistics/2012-Plastic-Surgery-Statistics/full-plastic-surgery-statisticsreport.pdf (accessed June 2014). 2013.

3. ASAPS: Cosmetic Surgery National Data Bank Statistics. New York, NY: The American Society for Aesthetic Plastic Surgery; 2013. 
4. Gartner LM, Morton J, Lawrence RA, Naylor AJ, O'Hare D, Schanler RJ, Eidelman Al: Breastfeeding and the use of human milk. Pediatrics 2005 115(2):496-506.

5. Kramer MS, Kakuma R: The Optimal Duration Of Exclusive Breastfeeding: A systematic Review. Geneva, Switzerland: World Health Organization; 2002

6. Cronemberger EV, Portocarrero ML, Donato AR, Cunha MS, Barreto TF, Meneses JVL: Use of the internet as a source of information about plastic surgery in Bahia, Brazil. Revista Brasileira de Cirurgia Plástica 2012, 27(4):531-535.

7. Walden JL, Panagopoulous G, Shrader SW: Contemporary decision making and perception in patients undergoing cosmetic breast augmentation. Aesthetic Surg J 2010, 30(3):395-403.

8. Gordon JB, Barot LR, Fahey AL, Matthews MS: The internet as a source of information on breast augmentation. Plast Reconstr Surg 2001, 107(1):171-176.

9. Jejurikar SS, Rovak JM, Kuzon WM Jr, Chung KC, Kotsis SV, Cederna PS: Evaluation of plastic surgery information on the internet. Ann Plast Surg 2002, 49(5):460-465.

10. Reid AJ, Malone PS: Plastic surgery in the press. J Plast Reconstr Aesthet Surg 2008, 61(8):866-869.

11. Roberts $C L$, Schiff M, Algert CS: Breastfeeding after augmentation mammoplasty: Protocol for a systematic review and meta-analysis. 2013, http://hdl.handle.net/2123/10394.

12. Wells G, Shea B, O'connell D, Peterson J, Welch V, Losos M, Tugwell P: The Newcastle-Ottawa Scale (NOS) for assessing the quality of nonrandomised studies in meta-analyses. In 3rd Symposium on Systematic Reviews: Beyond the Basics; July 3-5, 2000; Oxford, UK. Available at: http://www.ohri.ca/ programs/clinical_epidemiology/oxford.htm.

13. National Health and Medical Research Council: NHMRC Additional Levels of Evidence and Grades for Recommendations for Developers of Guidelines. Canberra, Australia: 2009. http://www.nhmrc.gov.au/_files_nhmrc/file/ guidelines/stage_2_consultation_levels_and_grades.pdf (accessed June 2014).

14. DerSimonian R, Laird N: Meta-analysis in clinical trials. Contr Clin Trials 1986, 7(3):177-188

15. Higgins JPT, Thompson SG: Quantifying heterogeneity in a meta-analysis Stat Med 2002, 21(11):1539-1558.

16. Cook LS, Daling JR, Voigt LF, de Hart MP, Malone KE, Stanford JL, Weiss NS, Brinton LA, Gammon MD, Brogan D: Characteristics of women with and without breast augmentation. JAMA 1997, 277(20):1612-1617.

17. Neifert M, DeMarzo S, Seacat J, Young D, Leff M, Orleans M: The influence of breast surgery, breast appearance, and pregnancy-induced breast changes on lactation sufficiency as measured by infant weight gain. Birth 1990, 17(1):31-38

18. Andrade RA, Coca KP, Abrão ACFV: Breastfeeding pattern in the first month of life in women submitted to breast reduction and augmentation. J Pediatr 2010, 86(3):239-244.

19. Cruz NI, Korchin L: Breastfeeding after augmentation mammaplasty with saline implants. Ann Plast Surg 2010, 64(5):530-533.

20. Hurst NM: Lactation after augmentation mammoplasty. Obstet Gynecol 1996, 87(1):30-34

21. ASPS: Plastic Surgery and Procedures in the US, III. Arlington Heights: American Society of Plastic Surgeons; 2011.

22. Michalopoulos $K$ : The effects of breast augmentation surgery on future ability to lactate. Breast J 2007, 13(1):62-67.

23. Slavin SA, Greene AK: Augmentation mammoplasty and its complications. In Grabb and Smith's Plastic Surgery. Edited by Horne C, Beasely R, Aston S, Bartlett S, Gurtner G, Spear S. Philadelphia: Lippincott-Raven; 2007:575-584

24. Gabriel SE, Woods JE, O'Fallon WM, Beard CM, Kurland LT, Melton LJ: Complications leading to surgery after breast implantation. New Engl J Med 1997, 336(10):677-682.

25. Handel N, Jensen JA, Black Q, Waisman JR, Silverstein MJ: The fate of breast implants: a critical analysis of complications and outcomes. Plast Reconstr Surg 1995, 96(7):1521-1533.

26. Acartürk $S$, Gencel $E$, Tuncer I: An uncommon complication of secondary augmentation mammoplasty: bilaterally massive engorgement of breasts after pregnancy attributable to postinfection and blockage of mammary ducts. Aesthetic Plast Surg 2005, 29(4):274-279.

27. Deloach ED, Lord SA, Ruf LE: Unilateral galactocele following augmentation mammoplasty. Ann Plast Surg 1994, 33(1):68-71.

28. Hill P, Wilhelm P, Aldag J, Chatterton R: Breast augmentation and lactation outcome: a case report. MCN Am J Matern Child Nurs 2004, 29(4):238-242.
29. Johnson PE, Hanson KD: Acute puerperal mastitis in the augmented breast. Plast Reconstr Surg 1996, 98(4):723-725.

30. Huggins K, Petok E, Mireles O: Markers of lactation insufficiency: a study of 34 mothers. In Current Issues in Clinical Lactation 2000. Edited by Auerbach K. Sudbury, MA: Jones and Bartlett; 2000:25-35

31. Beale S, Lisper HO, Palm B: A psychological study of patients seeking augmentation mammaplasty. Br J Psychiatry 1980, 136:133-138.

32. Didie ER, Sarwer DB: Factors that influence the decision to undergo cosmetic breast augmentation surgery. J Wom Health 2003, 12(3):241-253.

33. Sarwer DB: The psychological aspects of cosmetic breast augmentation. Plast Reconstr Surg 2007, 120(7):110S-117S

34. Sarwer DB, LaRossa D, Bartlett SP, Low DW, Bucky LP, Whitaker LA: Body image concerns of breast augmentation patients. Plast Reconstr Surg 2003, 112(1):83-90

35. Shaikh U, Sigman-Grant M: Breast augmentation and breastfeeding: knowledge and practices of surgeons in Las Vegas, Nevada. J Plast Reconstr Aesthet Surgs 2006, 59(4):434-436.

36. Dettwyler KA: Beauty and the breast: The cultural context of breastfeeding in the United States. In Breastfeeding: Biocultural Perspectives. Edited by Stuart-Macadam P, Dettwyler KA. New York: Aldine de Gruyter 1995:167-215.

37. Berry $\mathrm{NJ}$, Jones $\mathrm{S}$, Iverson D: It's all formula to me: women's understandings of toddler milk ads. Breastfeeding Review 2010, 18(1):21-30

38. Howard C, Howard F, Lawrence R, Andresen E, DeBlieck E, Weitzman M: Office prenatal formula advertising and its effect on breast-feeding patterns. Obstet Gynecol 2000, 95(2):296-303.

39. Li R, Rock VJ, Grummer-Strawn L: Changes in public attitudes toward breastfeeding in the United States, 1999-2003. J Am Diet Assoc 2007, 107(1):122-127.

40. FDA: FDA Breast Implant Consumer Handbook. Rockville, MD: Center for Devices and Radiological Health, US Food and Drug Administration; 2004.

41. Kessler DA: The basis of the FDA's decision on breast implants. New Eng J Med 1992, 326(25):1713-1715

42. Lugowski S, Smith D, Bonek H, Lugowski J, Peters W, Semple J: Analysis of silicon in human tissues with special reference to silicone breast implants. J Trace Elem Med Biol 2000, 14(1):31-42.

43. Semple JL, Lugowski SJ, Baines CJ, Smith DC, McHugh A: Breast milk contamination and silicone implants: preliminary results using silicon as a proxy measurement for silicone. Plast Reconstr Surg 1998, 102(2):528-533.

44. Kjøller K, McLaughlin JK, Friis S, Blot WJ, Mellemkjær L, Høgsted C, Winther JF, Olsen $\mathrm{JH}$ : Health outcomes in offspring of mothers with breast implants. Pediatrics 1998, 102(5):1112-1115.

45. Levine JJ, llowite NT: Sclerodermalike esophageal disease in children breast-fed by mothers with silicone breast implants. JAMA 1994 271(3):213-216.

46. Signorello LB, Fryzek JP, Blot WJ, McLaughlin JK, Nyrén O: Offspring health risk after cosmetic breast implantation in Sweden. Ann Plast Surg 2001 46(3):279-286.

47. Larson DL, Anderson RC, Maksud D, Grunert BK: What influences public perceptions of silicone breast implants? Plast Reconstr Surg 1994, 94(2):318-325. discussion 326-317.

48. Palcheff-Wiemer M, Concannon MJ, Conn VS, Puckett CL: The impact of the media on women with breast implants. Plast Reconstr Surg 1993, 92(5):779-785

49. Strom SS, Baldwin BJ, Sigurdson AJ, Schusterman MA: Cosmetic saline breast implants: a survey of satisfaction, breast-feeding experience, cancer screening, and health. Plast Reconstr Surg 1997, 100(6):1553-1557.

doi:10.1186/1746-4358-9-17

Cite this article as: Schiff et al:: The impact of cosmetic breast implants on breastfeeding: a systematic review and meta-analysis. International Breastfeeding Journal 2014 9:17. 